\title{
Demonstration of synonymy between the plant pathogens Pseudomonas avenae and Pseudomonas rubrilineans
}

\author{
B. A. Ramundo and L. E. Claflin* \\ Department of Plant Pathology, Throckmorton Hall, Kansas State University, Manhattan, KS 66506-5502, USA
}

(Received 3 April 1990; revised 5 June 1990; accepted 22 June 1990)

\begin{abstract}
Strains of Pseudomonas avenae Manns 1909 and Pseudomonas rubrilineans (Lee et al., 1925) Stapp 1928 were compared using physiological, biochemical and serological tests together with an examination of plant host range. Minor differences were found between the physiological and biochemical characteristics of the two pathogens, while no differences were detected in pathogenicity, host range, cellular protein profiles, direct fluorescent straining, and dot-immunobinding assays. $P$. avenae and $P$. rubrilineans were distinctly different from other nonfluorescent pseudomonads. We were unable to differentiate $P$. avenae strains from those of $P$. rubrilineans, and we propose that they be regarded as a single species, retaining the name Pseudomonas avenae.
\end{abstract}

\section{Introduction}

During a survey of pearl millet (Pennisetum glaucum) in northern Nigeria in 1984, a bacterial leaf disease was observed in nearly every planting (Claflin et al., 1989). Lesions, $3-25 \mathrm{~cm}$ in length, were usually confined within the leaf veins. Diseased leaf tissue yielded bacterial colonies on yeast extract/glucose/calcium carbonate agar medium (YDCA) (Dowson, 1957) and King's medium B (KB) (King et al., 1954), which were smooth, cream coloured, and non-fluorescent. The colonies closely resembled those of Pseudomonas avenae (Manns, 1909) (syn. P. alboprecipitans; Schaad et al., 1975). To identify the causal agent, we examined numerous other Pseudomonas spp; one of these, $P$. rubrilineans, the causal agent of red stripe in sugarcane (Saccharum officinarum) (Christopher \& Edgerton, 1930; Hayward, 1962; Lee et al., 1925), appeared to be similar to $P$. avenae.

In the work described here, the extent of this apparent similarity was determined by applying a range of criteria to nine isolates of $P$. avenae and 11 isolates of $P$. rubrilineans.

\section{Methods}

Bacterial strains and media. The strains used in this study are listed in Table 1 . In addition to $P$. avenae and $P$. rubrilineans, strains of the non-

Abbreviation: FITC, fluorescein isothiocyanate. fluorescent plant pathogens $P$. andropogonis and $P$. rubrisubalbicans, and the fluorescent $P$. syringae pv. syringae, were studied. Stock cultures were maintained on plates of YDCA at $4{ }^{\circ} \mathrm{C}$. Strains were lyophilized for long-term storage. Prior to each experiment, inocula from stock culture plates were restreaked on fresh YDCA and incubated for $24 \mathrm{~h}$ at $28^{\circ} \mathrm{C}$.

Biochemical and physiological tests. Arginine dehydrolase activity was determined by stabbing a culture into Thornley's medium 2A (Thornley, 1960) and recorded as positive if the medium turned red under anaerobic conditions. Media for determining malonate and citrate utilization, gelatin hydrolysis, oxidase production, and reduction of nitrate to nitrite, were obtained from Difco or made up according to the Difco Manual. Lipase activity was determined by the method of Sierra (1957). Hydrolysis of starch was determined by adding $2 \%(\mathrm{w} / \mathrm{v})$ soluble potato starch (Sigma) to nutrient agar (Difco) supplemented with yeast extract $\left(5 \mathrm{~g} \mathrm{l}^{-1}\right)$. Inoculated plates were incubated for $4 \mathrm{~d}$ at $28{ }^{\circ} \mathrm{C}$, and then flooded with $1 \%(\mathrm{v} / \mathrm{v})$ Lugol's iodine. Growth at $4{ }^{\circ} \mathrm{C}$ and $41^{\circ} \mathrm{C}$ was determined by incubating cultures on YDCA for a maximum of one month. Plates were examined weekly and scored positive if isolated single colonies were observed. Plates incubated at $41^{\circ} \mathrm{C}$ were wrapped in Parafilm and placed in a moisture chamber to prevent media from dehydrating.

Acid production from various carbohydrate and carbon sources was tested using the OF basal medium of Hugh \& Leifson (1953) (Difco) supplemented with the test compound at $1 \%(w / v)$. Acid production was scored positive if a colour change from green to yellow was observed throughout the length of the tube.

Hypersensitivity reactions were determined on tobacco (Nicotiana tabacum L. cv. 'Samsum') plants, essentially as described by Klement $e t$ al. (1964). Strains were grown overnight in nutrient broth (NBY) (Vidaver, 1967), and the cultures centrifuged at $13000 \mathrm{~g}$ for $10 \mathrm{~min}$. The pellets were resuspended in $12.5 \mathrm{mM}$-potassium phosphate buffer pH 7.1, centrifuged, washed two additional times in the same buffer, and adjusted to a cell concentration of 100 Klett units (KlettSummerson filter no. 66) (about $10^{7}$ cells $\mathrm{ml}^{-1}$ ). Cell suspensions were 
Table 1. Origins, designations and hosts of Pseudomonas strains used in this study

\begin{tabular}{|c|c|c|}
\hline Pseudomonas strain* & Plant host & Origin \\
\hline \multicolumn{3}{|l|}{ P. avenae } \\
\hline ATCC $19860^{\top}$ & Zea mays & Florida \\
\hline ICPB PA134 & Zea mays & Japan \\
\hline ICPB PA 135 & Zea mays & Japan \\
\hline ICPB PA138 & Zea mexicana & Japan \\
\hline $76-1$ & Zea mays & Florida \\
\hline $\mathrm{C}-10$ & Zea mays & Georgia \\
\hline VS-1 & Paspalum urvillei & Florida \\
\hline ATCC 19822 & Oryza sativa & Japan \\
\hline W-6-L & Pennisetum glaucum & Nigeria \\
\hline \multicolumn{3}{|l|}{ P. andropogonis } \\
\hline ATCC $23061^{\mathrm{T}}$ & Sorghum bicolor & Indiana \\
\hline ATCC 23062 & Zea mays & Indiana \\
\hline KS 74 & Sorghum bicolor & Kansas \\
\hline $\mathrm{Tx}-5$ & Sorghum bicolor & Texas \\
\hline PDDCC 6780 & Coffea arabica & Brazil \\
\hline \multicolumn{3}{|l|}{ P. rubrilineans } \\
\hline ATCC $19307^{\mathrm{T}}$ & Saccharum officinarum & Reunion \\
\hline NCPPB 522 & Saccharum officinarum & Mauritius \\
\hline NCPPB 931 & Saccharum officinarum & Australia \\
\hline NCPPB 3029 & Zea mays & Brazil \\
\hline NCPPB 3107 & Zea mays & Brazil \\
\hline NCPPB 3111 & Canna paniculata & Brazil \\
\hline NCPPB 3112 & Canna indica & Brazil \\
\hline NCPPB 3113 & Saccharum officinarum & Brazil \\
\hline PDDCC 1656 & Zea mays & Florida \\
\hline PDDCC 3106 & Zea mays & India \\
\hline PDDCC 3168 & Zea mexicana & India \\
\hline \multicolumn{3}{|l|}{ P. rubrisubalbicans } \\
\hline ATCC $19308^{\top}$ & Saccharum officinarum & United States \\
\hline PDDCC 793 & Saccharum officinarum & Australia \\
\hline PDDCC 2850 & Zea mays & Florida \\
\hline PDDCC 3109 & Saccharum officinarum & Sri Lanka \\
\hline PDDCC 6268 & Sorghum bicolor & New Zealand \\
\hline \multicolumn{3}{|l|}{ P. syringae } \\
\hline pv. syringae & & \\
\hline ICPB $146 \mathrm{~N}$ & $\begin{array}{l}\text { Sorghum vulgare var. } \\
\text { sudanense }\end{array}$ & Hungary \\
\hline
\end{tabular}

* ATCC, American Type Culture Collection, Rockville, MD, USA; NCPPB, National Collection of Plant Pathogenic Bacteria, Harpenden, Hertfordshire, UK; PDDCC, Plant Disease Division Culture Collection, Auckland, New Zealand; ICPB, M. P. Starr, International Collection of Plant Pathogenic Bacteria, Davis, CA, USA; 76-1, VS-1, R. E. Stall, University of Florida, Gainesville, FL, USA; C-10, N. W. Schaad, University of Georgia, Experiment, GA, USA; W-6-L, KS-74, Tx-5, Department of Plant Pathology, Kansas State University, Manhattan, KS, USA. A superscript T denotes a type strain.

infiltrated into the abaxial side of a mature tobacco leaf with a syringe until an area was water-soaked. Plants were maintained within a temperature range of $22-30^{\circ} \mathrm{C}$ with a minimum of $12 \mathrm{~h}$ of light; observations were made $24 \mathrm{~h}$ after infiltration.

Pathogenicity tests. Pathogenicity of the various strains was determined on maize (Zea mays) cv. Pioneer 3195 (Pioneer Hi-Bred International, Johnston, IA, USA) and cv. Gold Cup (Harris-Moran Seed Co., Rochester, NY, USA); grain sorghum (Sorghum bicolor) cv. 80B3039 (D. T. Rosenow, Texas A \& M University, Lubbock, TX, USA); pearl millet cv. Sidney Dwarf and cv. Serere 3A (D. J. Andrews, University of Nebraska, Lincoln, NE, USA); and sugarcane cv. 67500 (N. Zummo, Mississippi State University, Mississippi State, MS, USA). Four leaves of sugarcane were inoculated with each bacterial strain using a Hagborg device (Hagborg, 1970) about 4 weeks after emergence. Five plants each of corn, sorghum, and pearl millet were inoculated with each strain about two weeks after emergence and maintained in a greenhouse $\left(22-28^{\circ} \mathrm{C}\right)$ with automated misting $(6 \mathrm{~min}$ $\mathrm{h}^{-1}$ for $6 \mathrm{~h} \mathrm{~d}^{-1}$ ). Symptoms were recorded 2 weeks after inoculation.

Serological tests. P. avenae (ATCC 19860 and ICPB PA134), $P$. rubrilineans (ATCC 19307), $P$. andropogonis (ATCC 23061) and $P$. rubrisubalbicans (ATCC 19308) were used to produce antisera. The procedure was essentially as reported previously (Leach et al., 1987) except that the rabbits were injected intramuscularly. Injections continued until serial twofold agglutination titres exceeded $1: 2048$. Antisera were fractionated twice using ammonium sulphate (Allan \& Kelman, 1977), with a final concentration of $35 \%$ saturation. Fluorescein isothiocyanate (FITC) (Sigma) was used for conjugating the globulin fraction. Conjugation and direct staining were done by the methods of Allan \& Kelman (1977), except that merthiolate was not added prior to storage. Microscope slides were examined using an Olympus BH-2 microscope equipped with a $40 \times$ Neofluor objective, an FITC (UG-1) exciter filter and an L420 barrier filter. The dotimmunobinding assay was performed as described previously (Leach $e t$ al., 1987).

Cellular protein profiles. Cells were grown overnight in $5 \mathrm{ml}$ of NBY in a shaker bath at $28^{\circ} \mathrm{C}$. Cells were pelleted in a clinical centrifuge, resuspended in $20 \mathrm{ml}$ of cellular protein isolation buffer [ $10 \mathrm{mM}$-Tris hydrochloride, $30 \mathrm{~mm}-\mathrm{NaCl}, \mathrm{pH} 7.2$ (Sigma)], and maintained on ice for the remainder of the procedure. A quantity of cells equal to 1300 Klett units [Klett reading $\times$ volume of suspension $(\mathrm{ml})=1300 \mathrm{Klett}$ units] was centrifuged and resuspended in $1 \mathrm{ml}$ isolation buffer and $1 \mathrm{ml} 2 \times$ sample buffer $(2 \times$ sample buffer: $1.51 \mathrm{~g}$ Tris hydrochloride, $20 \mathrm{ml}$ glycerol, $4.0 \mathrm{~g} \mathrm{SDS}, 10 \mathrm{ml}$ mercaptoethanol, $20 \mathrm{mg}$ bromophenol blue, $100 \mathrm{ml}$ distilled water). Samples were boiled for $5 \mathrm{~min}$, cooled, and stored at $-20^{\circ} \mathrm{C}$. The buffer system for gel electrophoresis was that of Laemmli (1970). Polyacrylamide gel concentration and the procedure for protein band separation were as described by Qhobela \& Claflin (1988).

\section{Results}

\section{Phenotypic characteristics}

Differences between $P$. andropogonis, $P$. avenae, $P$. rubrilineans and $P$. rubrisubalbicans are shown in Table 2 . All four species were positive for acid production from arabinose, fructose and sorbitol, and for utilization of citrate, were positive for tobacco hypersensitivity, and grew at $4{ }^{\circ} \mathrm{C}$. None produced acid from cellobiose, melibiose or salicin.

\section{Serological tests}

$\boldsymbol{P}$. avenae and $\boldsymbol{P}$. rubrilineans could not be distinguished from one another by the dot-immunobinding assay using heterologous antiserum at the highest dilution of $10^{5}$ (approximately 400 cells) (Table 3). Cross-reactions were observed with $P$. andropogonis and $P$. rubrisubalbicans at lower dilutions (4000 cells) to both antisera. This crossreactivity was eliminated by decreasing the cell concentration. $P$. andropogonis and $P$. rubrisubalbicans reacted only with their homologous antisera at the highest dilutions. Neither $P$. avenae nor $P$. rubrilineans reacted with the antisera to the other pseudomonads. 
Table 2. Physiological and biochemical differences between $P$. andropogonis, $P$. avenae, $P$. rubrilineans and $P$. rubrisubalbicans

Symbols: + , positive; -, negative; S, slight; ND, not done. Numbers in parentheses indicate the number of strains giving that response when the response varied among strains of one species.

\begin{tabular}{|c|c|c|c|c|}
\hline Characteristic & $\begin{array}{l}\text { P. andropogonis } \\
\text { (4 strains)* }\end{array}$ & $\begin{array}{l}\text { P. avenae } \\
\text { (8 strains) } \dagger\end{array}$ & $\begin{array}{l}P . \text { rubrilineans } \\
\text { (11 strains) }\end{array}$ & $\begin{array}{l}\text { P. rubrisubalbicans } \\
\text { (5 strains) }\end{array}$ \\
\hline \multicolumn{5}{|l|}{ Acid production from: } \\
\hline Glucose & - & + & + & + \\
\hline Glycerol & - & + & + & + \\
\hline myo-Inositol & + & - & $-(7)$ & $-(2)$ \\
\hline Raffinose & - & - & $-(6)$ & - \\
\hline Rhamnose & - & - & $-(5)$ & - \\
\hline \multicolumn{5}{|l|}{ Hydrolysis of: } \\
\hline Starch & - & $\mathbf{s}$ & - & - \\
\hline Tween 80 & ND & + & + & - \\
\hline Growth at $41^{\circ} \mathrm{C}$ & - & + & + & + \\
\hline Utilization of malonate & + & + & - & + \\
\hline Nitrate reduction & ND & + & + & $-(2)$ \\
\hline \multicolumn{5}{|l|}{ Production of: } \\
\hline Arginine dehydrolase & - & - & - & + \\
\hline Lipase & - & + & + & - \\
\hline Oxidase & - & + & + & + \\
\hline
\end{tabular}

* ATCC 23061, ATCC 23062, KS 74, Tx-5.

$\dagger$ ATCC 19860, ICPB PA134, ICPB PA135, ICPB PA138, 76-1, VS-1, ATCC 19822, W-6-L.

Table 3. Reaction of Pseudomonas strains to antisera prepared against four non-fluorescent pseudomonads

+ , Positive reaction in the dot-immunobinding assay at $10^{5}$ c.f.u. $\mathrm{ml}^{-1} ;-$, negative reaction at $10^{5}$ c.f.u. $\mathrm{ml}^{-1}$.

\begin{tabular}{lcccc}
\hline \multicolumn{1}{c}{ Strain } & \multicolumn{4}{c}{ Antiserum raised against: } \\
\cline { 2 - 5 } \multicolumn{1}{c}{ P. andropogonis } & P. avenae & P. rubrilineans & P. rubrisubalbicans \\
\hline P. andropogonis ATCC 23061 & + & - & - & - \\
$P$. avenae ATCC 19860 & - & + & + & - \\
$P$. rubrilineans ATCC 19307 & - & + & + & - \\
$P$. rubrisubalbicans ATCC 19308 & - & - & - & - \\
$P$. syringae pv. syringae ICPB 146N & - & - & - & - \\
Water control & - & - & - & + \\
\hline \hline
\end{tabular}

\section{Immunofluorescent staining}

In the direct staining procedure, $P$. avenae cells stained positive when incubated with FITC-conjugated antiserum to $P$. rubrilineans, at an optimal dilution of $1: 64$. Results were also positive when $P$. rubrilineans cells were incubated with FITC-conjugated antiserum to $P$. avenae. However, fluorescence was not observed when the direct staining procedure was used with cells of $P$. andropogonis, $P$. rubrisubalbicans or $P$. syringae pv. syringae and antiserum to $P$. avenae or $P$. rubrilineans.

\section{$S D S-P A G E$}

The protein banding patterns (Fig. 1) of $P$. avenae (lane G) and $P$. rubrilineans (lanes $C$ and D) were indistinguishable from one another but clearly distinct from those of the other pseudomonads tested. $P$. avenae and $P$. rubrilineans had a very large, distinct band at $29 \mathrm{kDa}$, along with other common bands, which were not observed for the other pseudomonads tested.

\section{Pathogenicity tests}

All the strains of $P$. avenae and $P$. rubrilineans tested were pathogenic to maize, millet and sorghum, and with the exception of strain NCPPB 3112 of $P$. rubrilineans, all were pathogenic to sugarcane. The plant disease symptoms induced by $P$. avenae and $P$. rubrilineans were indistinguishable. On maize, water-soaked areas were often present around the lesions, which had translucent to light centres with dark brown margins. Millet lesions were light brown at the centre with dark brown margins; they were confined to interveinal tissue and extended up to $10 \mathrm{~cm}$. Water-soaking was limited to the edge of the margins. Sorghum lesions were tan-centred with dark red margins, while leaf veins near the margins were dark red. 


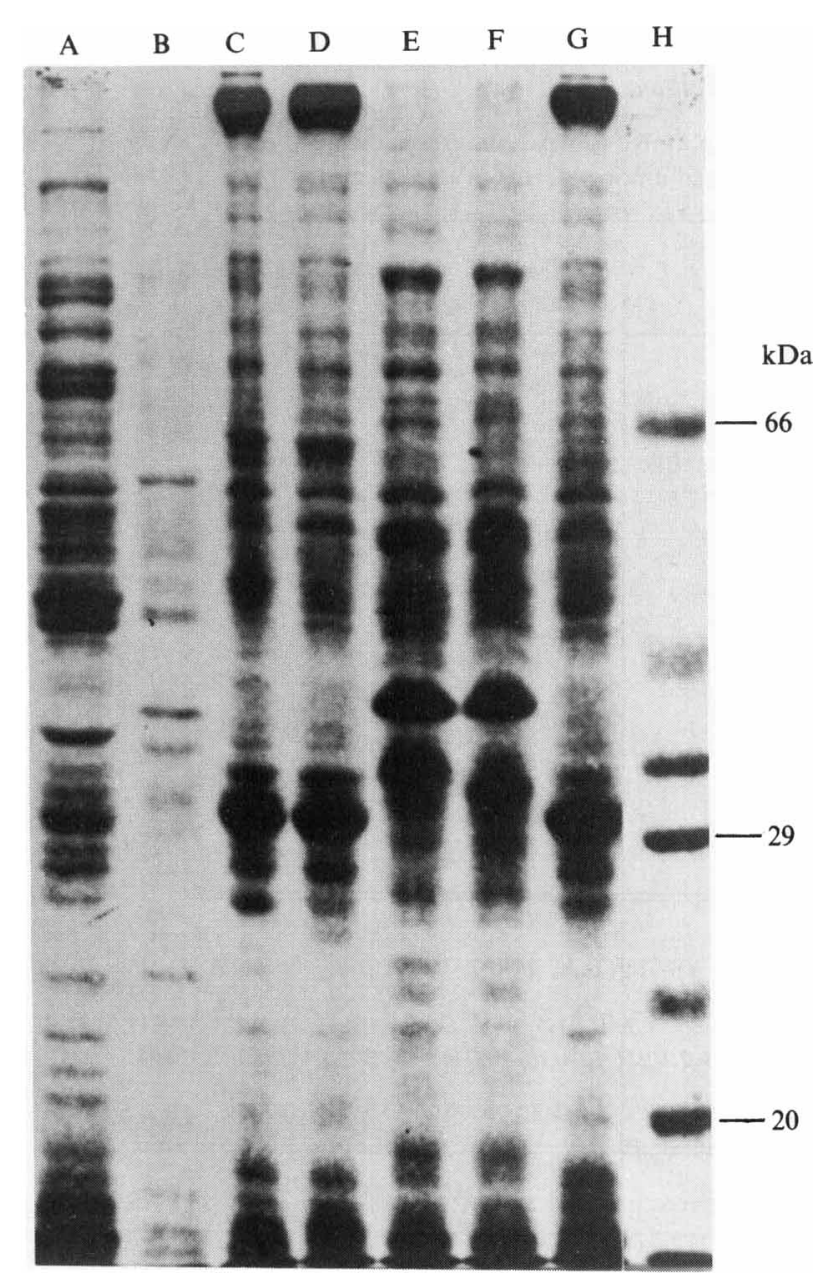

Fig. 1. SDS-PAGE of cellular proteins from Pseudomonas strains. Lanes: A, P. syringae pv. syringae ICPB $146 \mathrm{~N} ; \mathrm{B}, P$. andropogonis ATCC 23061; C, D, P. rubrilineans ATCC 19307 and PDDCC 3168; E, F, P. rubrisubalbicans PDDCC 3109 and PDDCC 793; G, P. avenae ATCC 19860; H, molecular mass markers (SDS-7 Dalton VII-L).

On sugarcane, elongated dark red lesions were intertwined and extended up to $45 \mathrm{~cm}$ in length.

Our strains of $P$. andropogonis were highly aggressive in maize and sorghum, mildly virulent in sugarcane and weakly aggressive in millet. Strains of $P$. rubrisubalbicans incited a variable pathogenic response in corn and sugarcane and were non-pathogenic or caused a hypersensitive reaction in millet and sorghum.

\section{Discussion}

$P$. avenae and $P$. rubrilineans are presently regarded as separate species, but our phenotypic tests showed only minor differences between them. $P$. avenae was positive for malonate utilization whereas $P$. rubrilineans was negative. The ability to produce acid from myo-inositol, raffinose and rhamnose was variable among the strains of $P$. rubrilineans and negative for all strains of $P$. avenae.

Twelve of the phenotypic characteristics tested were compared with those reported for $P$. rubrilineans (Hayward, 1962) and P. avenae (Schaad et al., 1975). Our results for $P$. rubrilineans were the same as those obtained by Hayward (1962). However, our strains of $P$. avenae were oxidase positive whereas Schaad et al. (1975) reported theirs to be oxidase negative. The ability of $P$. avenae to hydrolyse starch and gelatin was reported as slight or variable by Schaad et al. (1975), whereas our results were negative. However, $P$. andropogonis, the cause of leaf spots and streaks in numerous monocot and dicot hosts (Moffett et al., 1986), and P. rubrisubalbicans, a bacterium closely related to $P$. rubrilineans and the cause of mottled stripe on sugarcane (Christopher \& Edgerton, 1930) and leaf stripe of sorghum (Hale \& Wilkie, 1972), also exhibited only minor differences when compared to $P$. avenae and $P$. rubrilineans. Differentiation of species based solely on physiological and biochemical properties has always been difficult and, at times, subjective. The table of 16 different nonfluorescent pseudomonads given by Hayward (1983) exemplifies the problems encountered when differentiating bacterial species solely on the basis of such properties. While these properties are important and useful, other factors such as host range, symptomatology, serology, and comparison of protein profiles should be evaluated before taxonomic groupings are made.

Host range studies have reported $P$. avenae as naturally occurring on a wide variety of hosts including oats, barley, sorghum and wheat. $P$. rubrilineans has been associated mainly with sugarcane and sorghum. Both have been reported as being distributed worldwide. Our greenhouse studies failed to distinguish the two by host range or symptomatology on maize, sorghum, millet and wheat. The International Code of Nomenclature of Bacteria (Lapage et al., 1975) defines the pathovar as comprising bacteria that differ in 'pathogenic reactions in one or more hosts'. Since the symptomatology and host ranges were the same with $P$. avenae and $P$. rubrilineans, a pathovar designation would be invalid.

Dot-immunobinding assay procedures have proved both rapid and reliable in the identification of bacteria and viruses (Hsu, 1984; Leach et al., 1987). P. avenae and $P$. rubrilineans reacted equally well with both homologous and heterologous antisera, while $P$. andropogonis, $P$. rubrisubalbicans and $P$. syringae pv. syringae were positive with their homologous antisera only. Additional serological evidence for the apparent synonymy of $P$. avenae and $P$. rubrilineans was provided by their equivalent reactions to homologous and heterologous FITC-conjugated antisera in direct immunofluorescent staining. 
SDS-PAGE has been a valuable technique in bacterial identification and classification, and, at times, for the realignment of bacterial genera. Carlson \& Vidaver (1982) used gel analysis as a major factor in the taxonomic reclassification of the genus Corynebacterium. In our work, the total cellular protein profiles of $P$. avenae and $P$. rubrilineans were indistinguishable from each other and formed a distinct group when compared to other non-fluorescent pseudomonads.

$P$. avenae and $P$. rubrilineans have consistently been placed in the same taxonomic group. De Vos et al. (1985) assigned $P$. avenae (alboprecipitans) and $P$. rubrilineans to the $P$. acidovorans $\mathrm{rRNA}$ branch. Takikawa \& Shimaoka (1988) placed $P$. avenae in group C, which included $P$. acidovorans and Comamonas terriagena, on the basis of quinone and fatty acid profiles. Our results demonstrate that $P$. avenae and $P$. rubrilineans are synonymous. The name Pseudomonas avenae has priority and we propose that it be retained, with ATCC 19860 (NCPPB 1011) as the type strain.

We wish to thank Marie Ward for processing the manuscript.

This research was supported by the Sorghum/Millet Collaborative Research Support Program (INTSORMIL) AID/DAN-1254-G-SS5065-00 from the Agency of International Development, Washington, DC; United States Department of Agriculture/Kansas State University Linkage Contract no. 58-319R-O-256; and the Kansas Agricultural Experiment Station, Manhattan, KS 66506.

Contribution no. 88-219-J from the Kansas Agricultural Experiment Station, Kansas State University, Manhattan.

\section{References}

Allan, E. \& Kelman, A. (1977). Immunofluorescent stain procedures for detection and identification of Erwinia carotovora var. atroseptica. Phytopathology 67, 1305-1312.

CARLsON, R. R. \& VIDAver, A. K. (1982). Taxonomy of Corynebacterium plant pathogens, including a new pathogen of wheat, based on polyacrylamide gel electrophoresis of cellular proteins. International Journal of Systematic Bacteriology 32, 315-326.

Christopher, W. N. \& Edgerton, C. W. (1930). Bacterial stripe diseases of sugarcane in Louisiana. Journal of Agricultural Research 41, 259-267.

Claflin, L. E., Ramundo, B. A., Leach, J. E. \& ERinle, I. D. (1989). Pseudomonas avenae, causal agent of bacterial leaf stripe of pearl millet. Plant Disease 73, 1010-1014.

De Vos, P., GoOR, M., Gillis, M. \& De LeY, J. (1985). Ribosome ribonucleic acid cistron similarities of phytopathogenic Pseudomonas species. International Journal of Systematic Bacteriology 35, 169-184.

Dowson, W. J. (1957). Plant Diseases Due to Bacteria, 2nd edn. London: Cambridge University Press.

HAGBORG, W. A. F. (1970). A device for injecting solutions and suspensions into thin leaves of plants. Canadian Journal of Botany 48 , $1135-1136$.
HALE, C. N. \& WILKIE, J. P. (1972). Bacterial leaf stripe of sorghum in New Zealand caused by Pseudomonas rubrisubalbicans. New Zealand Journal of Agricultural Research 15, 457-460.

HaYWARD, A. C. (1962). Studies on bacterial pathogens of sugarcane II. Differentiation, taxonomy and nomenclature of the bacteria causing red stripe and mottled stripe diseases. Mauritius Sugar Industry Research Institute. Occasional Paper 13, 13-27.

Hayward, A. C. (1983). Pseudomonas: the non-fluorescent pseudomonads. In Plant Bacterial Diseases. A Diagnostic Guide, pp. 110-111. Edited by P. C. Fahy \& G. J. Persley. New York: Academic Press.

Hsu, Y. H. (1984). Immunogold for detection of antigen on nitrocellulose paper. Analytical Biochemistry 142, 221-225.

HUGH, R. \& Leirson, E. (1953). The taxonomic significance of fermentative versus oxidative metabolism of carbohydrates by various gram negative bacteria. Journal of Bacteriology 66, 24-26.

KING, E. O., WARD, M. K. \& RANEY, D. E. (1954). Two simple media for the demonstration of pyocyanin and fluorescin. Journal of Laboratory Medicine 44, 301-307.

KLement, Z., Farkas, G. L. \& LoVReKovich, L. (1964). Hypersensitive reaction induced by phytopathogenic bacteria in the tobacco leaf. Phytopathology 54, 474-477.

LAEMMLI, U. K. (1970). Cleavage of structural proteins during the assembly of the head of bacteriophage T4. Nature, London 227, 680685 .

Lapage, S. P., Sneath, P. H. A., Lessel, E. F., Skerman, V. B. D., SEeliger, H. P. R. \& Clark, W. A. (editors) (1975). International Code of Nomenclature of Bacteria, 1976 Revision. Washington, DC: American Society for Microbiology.

Leach, J. E., Ramundo, B. A., Pearson, D. L. \& Claflin, L. E. (1987). Dot-immunobinding assay for detection of Xanthomonas campestris pv. holcicola in sorghum. Plant Disease 71, 30-33.

Lee, H. A., Purdy, H. A., Barnum, C. C. \& Martin, J. P. (1925). Phytomonas rubrilineans. Hawaiian Sugar Planters' Association Bulletin no. 25.

MANNS, T. F. (1909). The blade blight of oats - a bacterial disease. Ohio Agricultural Experiment Station Research Bulletin 210, 91-167.

Moffett, M. L., Hayward, A. C. \& FaHY, P. C. (1986). Five new hosts of Pseudomonas andropogonis occurring in Eastern Australia: host range and characterization of isolates. Plant Pathology 35, 3443.

Qhobela, M. \& ClafLin, L. E. (1988). Characterization of Xanthomonas campestris pv. pennamericanum pv. nov., causal agent of bacterial leaf streak of pearl millet. International Journal of Systematic Bacteriology 38, 362-366.

SchaAd, N. W., KaDo, C. I. \& SUMNer, D. R. (1975). Synonymy of Pseudomonas avenae Manns 1905 and Pseudomonas alboprecipitans Rosen 1922. International Journal of Systematic Bacteriology 25, 133137.

SIERRA, G. (1957). A simple method for the detection of lipolytic activity of microorganisms and some observations on the influence of the contact between cells and fatty substrates. Antonie van Leeuwenhoek 23, 15-22.

STAPP, C. (1928). Schizomycetes (Spaltpilze oder Bakterien). In Handbuch der Pflanzenkrankheiten, 5th edn, vol. 2, pp. 1-295. Edited by P. Sorauer. Berlin: Paul Parey.

TAKIKAWA, M. \& SHIMAOKa, M. (1988). Grouping of phytopathogenic pseudomonads based on the analyses of quinones and fatty acids. (abstract). Sth International Congress of Plant Pathology, 1-4, p. 84.

THORNLEY, M. J. (1960). The differentiation of Pseudomonas from other Gram negative bacteria on the basis of arginine metabolism. Journal of Applied Bacteriology 23, 37-52.

VIDAVER, A. K. (1967). Synthetic and complex media for the rapid detection of fluorescence of phytopathogenic pseudomonads: effect of the carbon source. Applied Microbiology 15, 1523-1524. 